\title{
Biosynthesis of Silver Nanoparticles from the Marine Microalga Isochrysis galbana and their Antibacterial Activity Against Pathogenic Bacteria
}

\author{
Soad M. Mohy E-Din ${ }^{{ }^{*}}$ and Heba S. El Said ${ }^{2}$ \\ ${ }^{1}$ Botany and Microbiology Department, Faculty of Science, \\ Alexandria University and ${ }^{2}$ National Institute of Oceanography \\ and Fisheries, Alexandria, Egypt.
}

\begin{abstract}
URRENTLY, there is a growing need to develop environmentally benign nanoparticle synthesis process that does not use toxic chemicals in the synthesis protocols. Synthesis of nanomaterials by biological approach is innovative, cheaper and environmentally friendly. In this regard, the present study focused on the synthesis of silver nanoparticles from the microalga Isochrysis galbana. The silver nanoparticle produced by marine microalga Isochrysis galbana when incubated with silver nitrate solution at the same culture condition for $24 \mathrm{~h}$ and was detected by UV-Vis spectrophotometer, Energy dispersive X-ray (EDX-ray) and Transmission electron microscope. The synthesized silver nitrate nanoparticles from the marine microalga Isochrysis galbana showed the pronounced antibacterial activity against the tested human pathogens Escherichia coli and Proteus vulgaris. The above eco-friendly synthesis procedure of silver nitrate nanoparticles could be easily scaled up in future for the industrial and therapeutic needs.
\end{abstract}

Keywords Silver nanoparticles, Isochrysis galbana, Antibacterial activity.

An important aspect of nanotechnology is the development and synthesis of nanoparticles which is considered as a big challenge. Nanoparticles are being viewed as fundamental building blocks of nanotechnology. The development of the biologically inspired experimental process for the synthesis of nanoparticles is evolving into an important branch of nanotechnology (Dhanalakshmi et al., 2012). Nanoparticles of metals have been extensively researched because of their unique physical properties, chemical reactivity and potential applications in catalysis, biological labeling, biosensing drug delivery, antibacterial activity, antiviral activity, detection of genetic disorders, gene therapy and DNA sequencing (Thirumurugan et al., 2010).

Benthic marine algae are the group of algae that live either in marine or brackish water environment. The synthesis of nanoparticles using algae as a source has been unexplored and underexploited. More recently, there are few

*Corresponding auther : (E-mail: dr.soad_mohi@hotmail.com) 
investigations reported that algae being used as a biofactory for synthes is of metallic nanoparticles. In an important report, Singaravelu et al. (2007) implemented an efficient approach for the synthesis of stable gold nanoparticles by the reduction of aqueous $\mathrm{Aucl}_{4}$ by using Sargassum wightii. Recently Kumar et al. (2012) showed higher antibacterial activity of silver nanoparticles synthesized by Sargassum tenterrimum compared to the phytochemicals present. Devina Merin et al. (2010) and Kathiraven et al. (2014) showed that the marine microalgae rapidly synthesize silver nanoparticles with high efficient of antibacterial activity against human pathogens.

The silver nanoparticles are playing a major role in the field of nanotechnology and nanomedicine. A number of living organisms are already well known to elaborate silver nanostructured compounds such as cyanobacteria, bacteria, actinomycetes and plants as Cinnamomum camphora (Huth and Kwon, 2011) and Pelargonium graveolens (Lukman et al., 2011). Biosynthes is of silver nanoparticles using the marine seaweed Sargassum wightii was carried out by Shanmugam et al. (2013). In our present study, we report the synthes is of silver nanoparticles using the marine microalga Isochrysis galbana and also assess their antagonistic effect against some pathogenic bacteria.

\section{Tested alga}

\section{Material and Methods}

The marine microalga Isochrysis galbana (Haptophyceae) was obtained from the Institute of Oceanography and Fisheries in Alexandria (ARE) The algal culture was maintained in Walne's medium under uEs -1m -2 light intensity with photoperiod of $16 / 8$ light / dark cycle at $25^{\circ} \mathrm{C}$. The growth of Isochrysis galbana was monitored by measuring the optical density (OD) at $600 \mathrm{~nm}$ (with a Pharmacia Biotech spectrophotometer). The exponential phase of algal cells was recorded for the first 15 days.

\section{Synthesis of silver nanoparticles and preparation of extract}

The biosynthesis of silver nanoparticles from marine microalga Isochrysis galbana was performed as follow; the algal culture from mid exponential phase of its growth at ninth day was collected by centrifugation at $5000 \mathrm{rpm}$ for $5 \mathrm{~min}$ and the pellets were washed with sterile distilled water to remove the traces of media salts. The cell filtrate and biomass of $5 \mathrm{ml}$ was mixed with $95 \mathrm{ml}$ of silver nitrate solution $(1 \mathrm{mM})$ and incubated in the previous temperature and light conditions for $24 \mathrm{hr}$. During the incubation period, change in color of culture from pale yellow to dark brown indicates nanoparticle synthesis. Capping of micro algal proteins metabolites and reduction of silver ions may lead to formation of silver nanoparticles in the solution (Sudha et al., 2013).

Antibacterial sensitivity test

The microorganisms used for the antibacterial activity assay were Escherichia coli (E. coli) and Proteus vulgaris (gram negative bacteria) which were obtained from National Institute of Oceanography and fisheries, Alexandria. The antibacterial sensitivity test was done to detect whether silver Egypt. J. Bot., 56, No. 2 (2016) 
nanoparticle has any antagonistic effect against the chosen pathogenic bacteria using Muller Hinton agar and blood agar plates and gel puncture. The $\mathrm{pH}$ of medium was maintained at 7.4 and then it was sterilized by autoclaving at $121^{\circ} \mathrm{C}$ and $15 \mathrm{Ibs}$ pressure for $15 \mathrm{~min}$. $20 \mathrm{ml}$ of the sterilized medium was poured into sterilized petri dishes and allowed to solidify at room temperature. Each strain was swabbed uniformly onto the individual plates using sterile cotton swabs. In each of these plates 5-mm diameter wells were made at the center using an appropriate size sterilized cork borer. Different concentrations of the nanoparticles solution $(5,10$ and $20 \mu \mathrm{l})$ were poured into each well $(5-\mathrm{mm})$ on all plates ( Nathan et al., 1978). After incubated at $37^{\circ} \mathrm{C}$ for $24 \mathrm{hr}$, the different zones of inhibition of bacteria were measured $(\mathrm{mm})$ (Senthil and Kamaraj, 2011). The assays were performed in triplicate.

Detection and confirmation of silver nanoparticles

Ultraviolet (UV-vis) spectrum (Shimadzu UV- 1601 spectrophotometer), EDX ray analysis as well as transmission electron microscopy were used to detected and confirm the nanoparticle production.

\section{Results}

The stationary phase of Isochrysis galbana algal cells was recorded after 15 days of culturing and then growth started to decline (Fig. 1).

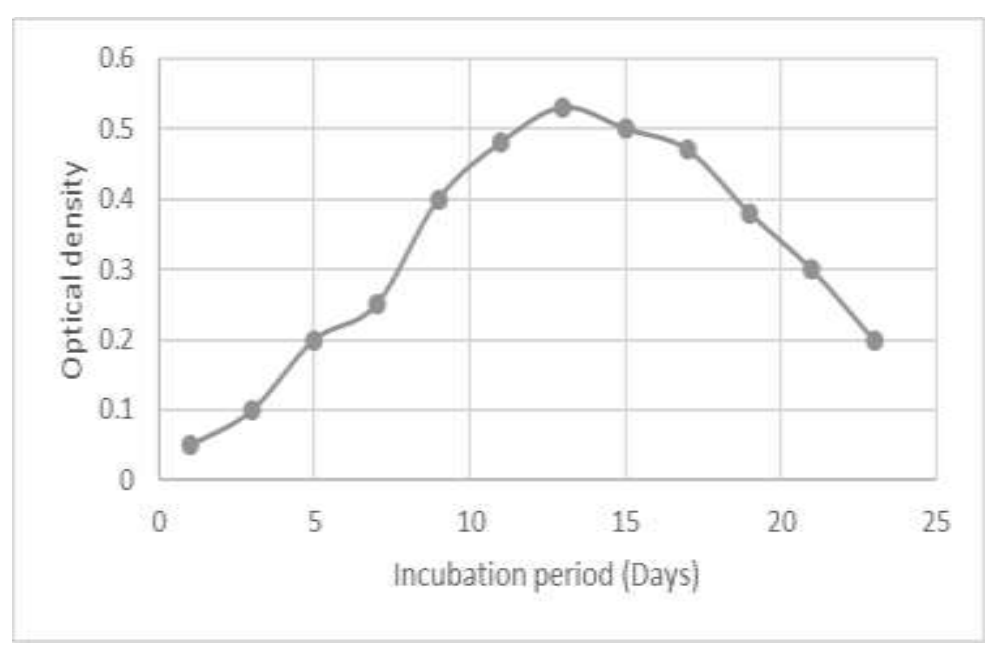

Fig. 1. Growth curve of Isochrysis galbana, each value is a mean of five replicates. 
Synthesis of silver nanoparticles

The appearance of brownish black color in the culture solution of Isochrysis galbana suggested the formation of silver nanoparticles with the plasmon resonance peak at $440 \mathrm{~nm}$. Thus, it was evident that the metabolites excreted by the alga exposed to silver could reducesilver ions, this may indicate that the reduction of the ions occur through electron shuttle or through reducing agents released into the solution by the alga. These reactions only occurred in the light and the nanoparticles were not produced in the dark. On the other hands, the reduction of silver ions did not occur in the absence of algal cells. The plasmon resonance observed at $440 \mathrm{~nm}$ for silver nanoparticles produced by normal marine microalga was shown in Fig. 2. The transmission electron microscopy has been used to identify the silver nanoparticles produced by marine microalga Isochrysis galbana (Fig. 3). Energy-dispersive X-ray (EDX) spectroscopy analysis for the confirmation of elemental silver was carried out for the detection of bioavailable metals at the subcellular level of an organis $m$ which may be bounded to a suspended particle of tested organism. (Fig. 4).

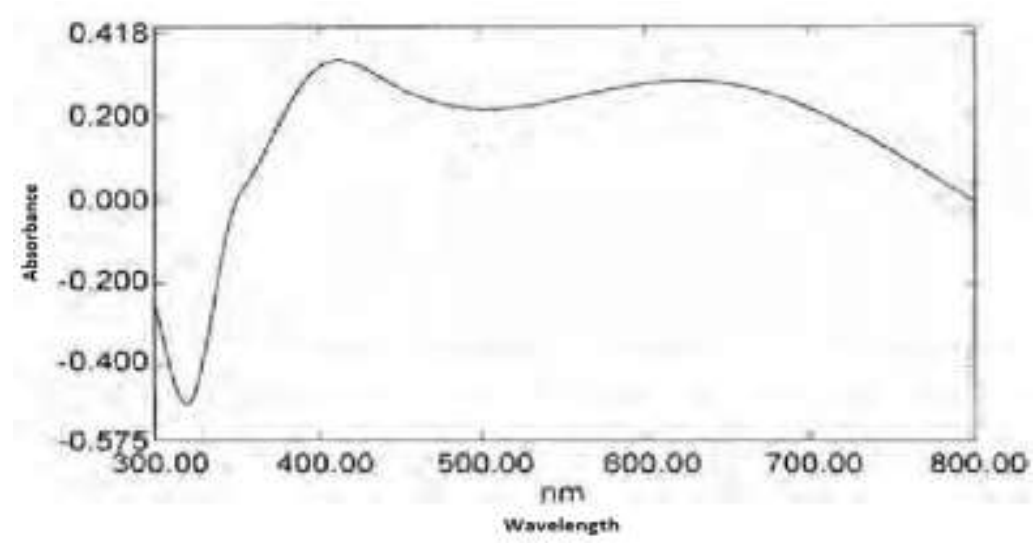

Fig. 2 . The UV- Vis spectra of silver nanoparticles produced. (Silver nitrate solutions incubated with marine microalga Isochrysis galbana).

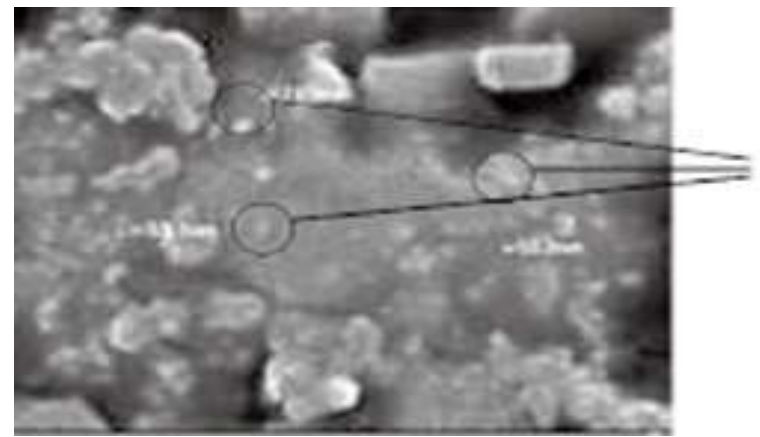

Silver

Nanoparticles

Fig. 3. Transmission electron microscope of the silver nanoparticles produced by marine microalga Isochrysis galbana

Egypt. J. Bot., 56, No. 2 (2016) 


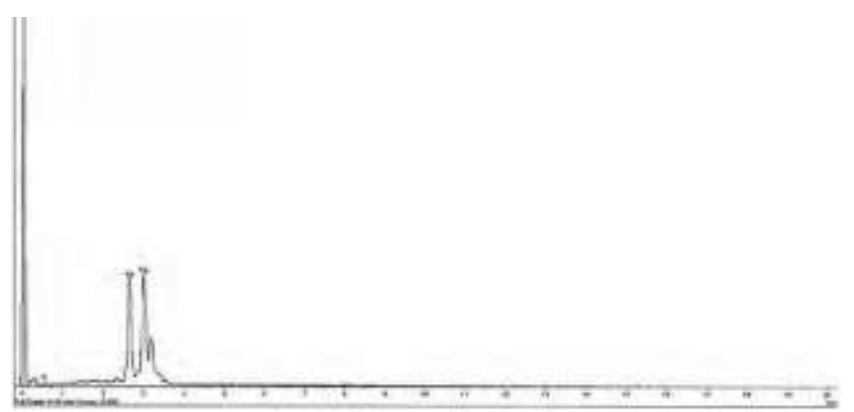

Fig. 4. Energy-dispersive X-ray (EDX) analysis of the silver nanoparticles produced by marine microalga Isochrysis galbana confirmed the elemental composition of nanoparticles as silver

\section{Antibacterial sensitivity test}

The results obtained from the present study concerning the biological activity of the antibacterial agents produced by Isochrysis galbana synthesized silver nanoparticles against two different species of bacteria with various

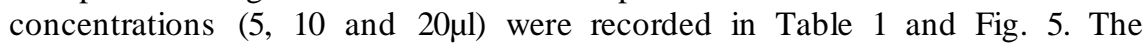
maximum antibacterial activity was found in Proteus vulgaris $(17 \mathrm{~mm}$ for $20 \mu \mathrm{l})$ and minimum level of antibacterial activity was noticed in Escherichia coli $(6 \mathrm{~mm}$ for $5 \mu \mathrm{l}$ ). Antibacterial activity was shown to be concentration dependent, i.e the diameter of inhibition zone increased with elevation of solution concentration $(5,10$ and $20 \mu \mathrm{l})$.

TABLE 1. Antibacterial activity of sliver nanoparticles against Escherichia coli and Proteus vulgaris (each value is a mean of three replicates).

\begin{tabular}{|c|c|c|c|c|}
\hline Test bacteria & $\begin{array}{c}\text { Concentration of silver } \\
\text { nanoparticle solution }(\boldsymbol{\mu l})\end{array}$ & 5 & 10 & 20 \\
\hline Escherichia coli & Zone of inhibition $(\mathrm{mm})$ & 6 & 9 & 14 \\
\hline Proteus vulgaris & & 8 & 11 & 17 \\
\hline
\end{tabular}

\section{Discussion}

The synthesis of nanoparticles is in the lime light in modern nanotechnology. The development of biologically inspired experimental processes for the synthesis of nanoparticles is evolving into an important branch of nanotechnology. In the present study, Isochrysis galbana was collected from the mid exponential phase of its growth and was cultivated along with silver nitrate solution. Upon addition of $\mathrm{Ag}^{+}$ions into the cell free culture in the light, samples changed color from pale yellow to dark brown with intensity increasing during 
the period of incubation. It showed no change in color of the cell filtrate (free algal cells) in control when incubated in the same condition. The appearance of a yellowish to dark brown color in solution was a clear indication of the formation of silver nanoparticles in the reaction mixture. The mechanism of action of silver nanoparticles synthesis was not known, but it was hypothesized that the silver ions required the NADH-dependent nitrate reductase enzyme for their reduction (Labrenz et al., 2000 and Shankar et al. (2003). Shankar et al., 2003 suggested that shoulder at $370 \mathrm{~nm}$ (UV-vis spectra in Fig. 2) corresponded to the transverse plasmon vibration in silver nanoparticles, whereas the peak at $440 \mathrm{~nm}$ was due to excitation of longitudinal plasmon vibration (Shankar et al., 2004). After $24 \mathrm{hr}$, the process was stopped and the particles were further detected by transmission electron microscope. The energy dispersive X-ray spectroscopy analysis of the silver nanoparticles confirmed the elemental composition of nanoparticles as silver by sharp signals (Fig. 4). The optical absorption band peak in the range of 3-4 $\mathrm{KeV}$ is typical for the absorption of metallic silver nanocrystallites recorded by Magudapathy et al. (2001).

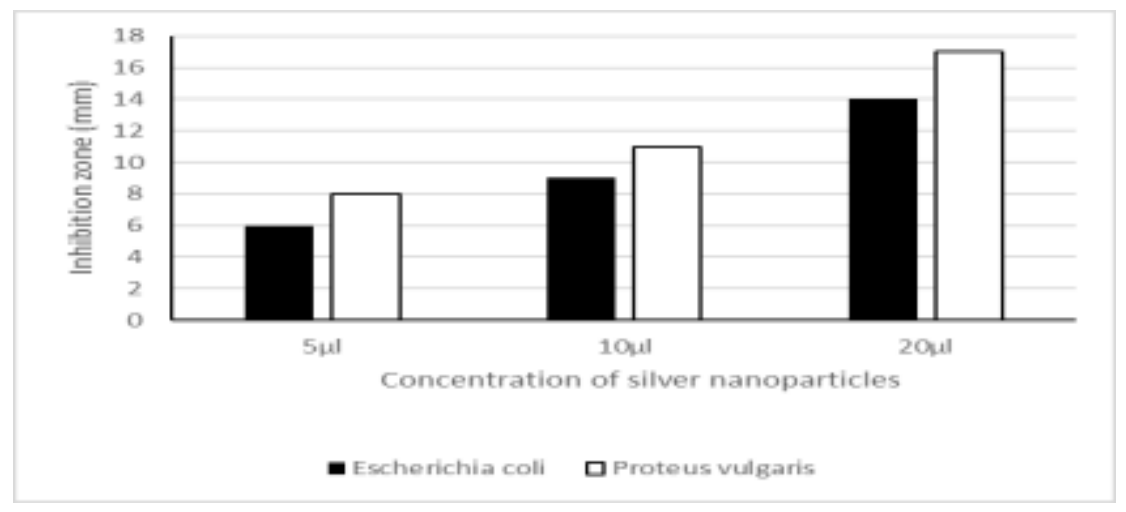

Fig. 5. Antibacterial activity of sliver nanoparticles against Escherichia coli and Proteus vulgaris.

The antibacterial activity of Isochrysis galbana synthesized silver nanoparticles were tested against Escherichia coli and Proteus vulgaris using various concentrations $(5,10$ and $20 \mu \mathrm{l})$ and results were shown in Table 1 and Fig. 5. Maximum zone of inhibition was found in Proteus vulgaris $(17 \mathrm{~mm}$ for $20 \mu \mathrm{l})$ and the minimum antibacterial activity was observed in Escherichia coli $6 \mathrm{~mm}$ for $5 \mu \mathrm{l}$ ). This difference in activity may be due to the susceptibility of the organism used in the current study. The nanoparticles are attached to the cell membrane and penetrated inside the bacterial cells. When silver nanoparticles enter the bacterial cell, it forms a low molecular weight compound in the center of the bacteria to which the bacteria conglomerates thus protecting the DNA from the silver ions. The nanoparticles preferably attack the respiratory chain cell division finally leading to the cell death (Kvitek et al., 2008). The nanoparticles release silver ions in the bacterial cells which enhance their Egypt. J. Bot., 56, No. 2 (2016) 
bacterial activity (Morones et al., 2005 and Kathiraven et al., 2014). Several studies proposed that silver nanoparticles may be attached to the surface of the cell membrane, disturbing permeability and respiration functions of the cell (Morones et al., 2005 and Rajeshkumar1 et al., 2013). It may also possible that silver nanoparticles not only interact with the surface of membrane, but it can also penetrate inside the bacteria (Sondi and Salopek, 2007).

Metallic silver is relatively unreactive, however, when exposed to aqueous environments some ionic silver $\left(\mathrm{Ag}^{+}\right)$is released. Certain salts (e.g. silver nitrate) are readily soluble in water and have exploited as antiseptic agents for many decades (Lansdown, 2002). Silver nanoparticles have been demonstrated to exhibit antibacterial properties against certain pathogenic bacteria (Sondi and Salopek, 2007).

\section{Conclusions}

It is concluded that the rapid biological synthesis of silver nanoparticles by marine microalgae provides a simple and efficient route for the synthesis of nanoparticles with tunable optical properties directed by particle size. Investigation on the antibacterial effect of nanosized silver colloidal solution against human pathogens revealed high efficacy of silver nanoparticles as a strong antibacterial agent, which can be useful in food industries, cosmetic industries and in pharmaceuticals. In addition, they are eco-friendly, economically low cost, ... ect. Future prospects of this research would be to scale-up the biosynthetic production of silver nanoparticles using this alga and to prove its efficacy against a wide spectrum of microbial population.

\section{References}

Devina Merin, D., Prakash, S. and Valentine Bhimba, B. (2010) Antibacterial screening of silver nanoparticles synthesized by marine micro algae. Asian Pacific journal of tropical Medicine. 797- 799.

Dhanalakshmi, P., Riyazulla, A., Rekha, R., Poonkodi, S. and Thangaraju, N. (2012) Synthesis of silver nanoparticles using green and brown seaweeds. Phycolo. Soc. 2, $39-45$.

Huth, A.J. and Kwon, Y,J. (2011) Nan antibiotics: a new paradigm for treating infectious diseases using nanomaterials in the antibiotics resistant era. J. Control Release. 156, 128- 145.

Kathiraven, T., Sundaramanickam, A., Shanmugam, N. and Balasubramanian, T., (2014) Green synthesis of silver nanoparticles using marine algae Caulerpa racemosa and their antibacterial activity against some human pathogens. Appl. Nanosci, 4,13204-014-0341-2. 
Kvitek, L., Panacek, A., Soukupova, J., Kolar, M., Vecerova, R., Prucek, R., Holecova, M. and Zboril, R. (2008) Effect of surfactants and polymers on stability and antibacterial activity of silver nanoparticles. J. Phys Chem.121, 5825- 5834.

Kumar, P., Senthamil, S., Lakshmi, P., Prem Kumar, K., Ganeshkumar, R.S. and Govindaraju, M. (2012) Synthesis of silver nanoparticles from Sargassum tenerrimum and screening phytochemicals for its antibacterial activity. Nano Biomed. Eng. 4, 12-16.

Lansdown, ABG. (2002) Silver 1: Its antibacterial properties and mechanism of action. $J$. Wound Care. 11, 125- 130.

Labrenz, M., Druschel, G.K., Thomsen, E.T., Gilgret, B., Welch, S. and Kemner, K. (2000) Formation of sphalertie $(\mathrm{ZnS})$ deposits in natural biofilms of sulfate- reducing bacteria. Science. 1744.

Lukman, A.I., Gong, B., Marjo, C.E., Roessner, U. and Harris, A.T. (2011) Facile synthesis, stabilization and anti-bacterial performance of discrete Ag nanoparticles using Medicago sativa seed exudates. J. Colloid Interface Sci. 353, 433-444.

Magudapathy, P., Gangopadhyay, P., Panigrahi, B., Nair, K. and Dhara, S. (2001) Electrical transport studies of Ag nanocrystallites embedded in glass matrix. Physics B. 299,142.

Morones, J,R., Elechiguerra, J.L., Camacho, A. and Ramirez, J.T. (2005) The bactericidal effect of silver nanoparticles. Nanotehnology. 16, 2346- 2353.

Nathan, P., Law, E.J. and Murphy, D. (1978) A laboratory method for selection of topical antimicrobial agent to treat infected burn wounds. Burns. 4, 177- 178.

Rajeshkumar1, S., Malarkodi1, C., Vanaja1, M., Gnanajobitha, C., Paulkumar1 C., Kannan C. and Annadurai1, G. (2013) Antibacterial activity of algae mediated synthesis of gold nanoparticles from Turbinaria conoides, Der Pharma Chemica. 5(2), 224-229.

Senthil, K.S. and Kamaraj, M. (2011) Antimicrobial activity of Cucumis anguria L by agar well diffusion method. 201 Bot Res Int. 4, 41-42.

Shanmugam, N., Rajkamal, P., Cholan, S., Kannadasan, N., Sathishkumar, K., Viruthagiri, G. and Sundaramanickam, A. (2013) Biosynthesis of silver nanoparticles from the marine seaweed Sargassum wightii and their antibacterial activity against some human pathogens. Appl. Nanosci. 4,13204-013-0271.

Shankar, S., Ahmad, A. and Sastry, M. (2003) Geranium leaf assisted biosynthesis of silver nanoparticles. Biotechnol. Prog. 1627.

Shankar S., Rai A., Ahmad A. and Sastry M. (2004) Transverse plasmon vibration in silver nanoparticles, J. Colloid Interface Sci. 275, 496.

Singaravelu, G., Arockiamary, J., Ganesh Kumar, V. and Govindaraju, K. (2007) A noval extracellular synthesis of monodisperse gold nanoparticles using marine alga, Sargassum wightii. Colloids Surf. Biointerfaces. 57, 97-101.

Egypt. J. Bot., 56, No. 2 (2016) 
Sondi, I. and Salopek, S.B. (2007) Silver nanoparticles antimicrobial agent a case study on $E$. coli as a model for gram negative bacteria. J. Colloid Interface Sci. 275, 177- 182.

Sudha, S., Karthic, R. and Rengaramanujam, J. (2013) Microalgae mediated synthesis of silver nanoparticles and their antibacterial activity against pathogenic bacteria. Indian J. Experimental Biology. 52, 393-399.

Thirumurugan, A., Jiflin, G., Rajagomathi, G., NeethuAnns, Tomy., Ramachandran, S. and Jaiganesh, R. (2010) Synthesis of gold nanoparticles of Azadirachta indica leaf extract, International J.Biological Techno. 1, 75-77.

(Receved 12/8/2015;

accepted $16 / 9 / 2015$

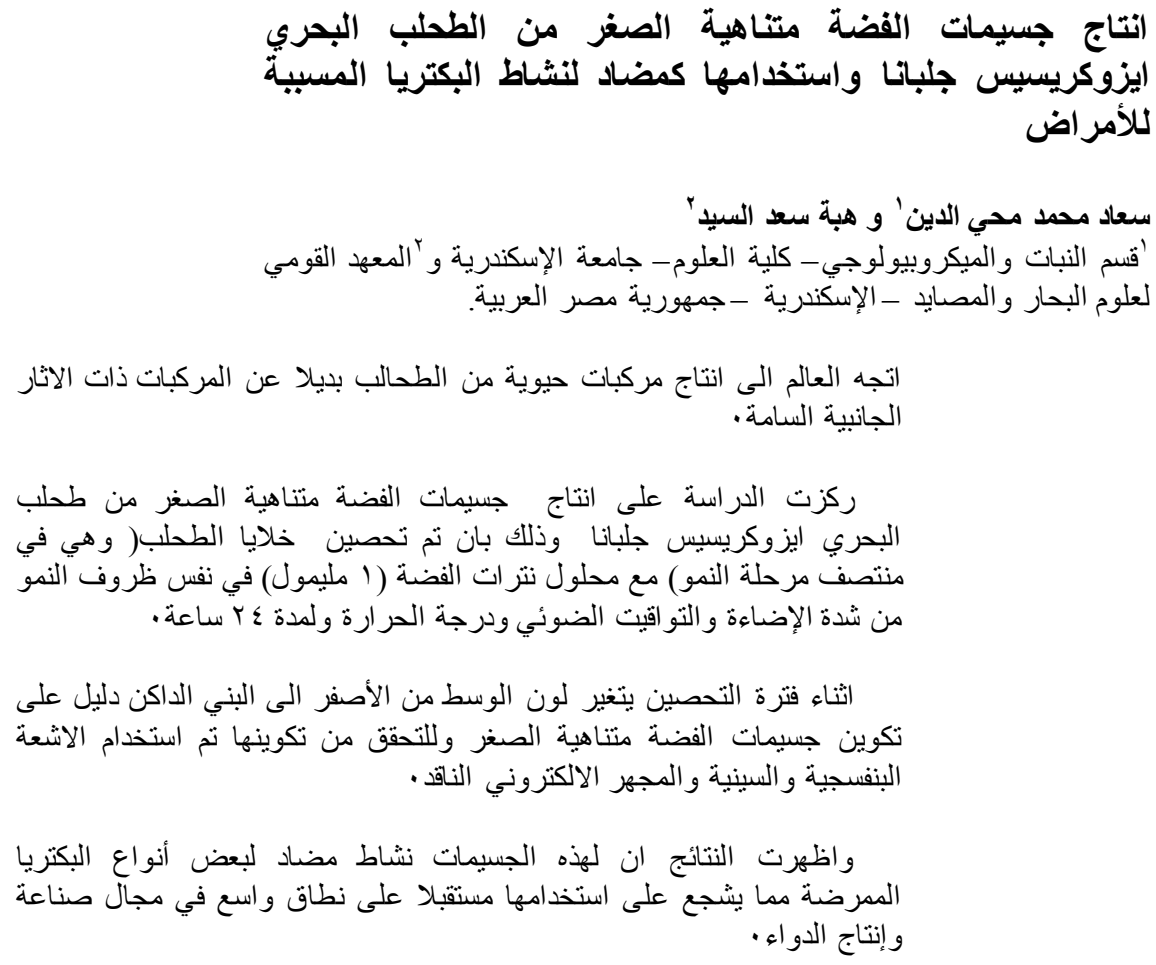


